\title{
INVESTIGATION OF MECHANICAL AND ELASTIC STRESSES IN ANSYS PROGRAM BY FINITE ELEMENTS METHOD OF 3D LATTICE ROOF MODEL
}

\author{
${ }^{*}$ Semih TAŞKAYA \\ Firat University, Faculty of Technology,Department of Metallurgical and Materials Engineering, TURKEY \\ muh.semihtaskaya@gmail.com \\ iD https://orcid.org/0000-0003-1524-4537 \\ Received: 28.01. 2018, Accepted: 19.05.2018 \\ *Corresponding author \\ Research Article \\ DOI:10.22531/muglajsci.399522

\begin{abstract}
In this study, the lattice roof model was designed in 3 dimensions using the finite element method in the Ansys package program. This method can be understood by making the complex engineering applications is a method to provide the solution can be controlled by the system. The element type of the model, the outside diameter of the truss pipe, the thickness of the meat, the modulus of elasticity and the poisson ratio parameters are defined as material properties. The material is a steel isotropic material. A total of mechanical and elastic stress analyzes were carried out under the constant load of 25000 and $20000 \mathrm{kN}$ applied to $F_{x}, F_{y}, F_{z}$ beam axes and $2 \mathrm{MPa}$ pressure on the $3 D$ lattice roof model. Deformations of the model against the load were investigated by analyzing the stresses against the mechanical forces and the elastic stresses in the $x, y, z$ axes. As a result of the analyses, it was observed that the mechanical and elastic stresses in the beam axes against the applied load increased.
\end{abstract}

Keywords: Finite Elements Method, Ansys, 3D Lattice Systems, Mechanical and Elastic Stress.

\section{D KAFES ÇATI MODELİNIN SONLU ELEMANLAR YÖNTEMIYLE ANSYS PROGRAMINDA MEKANIK VE ELASTIK GERILMELERINININ İNCELENMESİ}

$\ddot{0} \mathbf{z}$

Bu çalışmada, kafes çatı modeli Ansys paket programında, sonlu elemanlar yöntemi kullanılarak 3 boyut olarak tasarlandı. Bu yöntem, kompleks mühendislik uygulamalarının anlaşılabilir hale getirilerek, kontrol edilebilir sistemlerle çözümünü sağlayan bir metottur. Modelin element tipi, kafes boru dış çap, et kalınlığı, elastisite modülü ve poisson oranı parametreleri malzeme özelliklerine tanımlanır. Malzeme çelik izotropik bir malzemedir. $3 D$ kafes çatı modeline $F_{x}, F_{y}, F_{z}$ kiris eksenlerine uygulanan 25000 ve 20000 kN'luk sabit yük ve 2 MPa basınç altında toplam mekanik ve elastik gerilme analizleri yapıld. Modelin $x, y, z$ eksenlerinde mekanik zorlanmalara karşı gerilme ve elastik stres gerilme analizleri yapılarak yüke karşı göstermiş olduğu deformasyon şekil değişimleri incelendi. Analizler sonucunda, uygulanan yüke karşı oluşan kiriş eksenlerindeki mekanik ve elastik gerilmelerin arttığı görüldü.

Anahtar Kelimeler: Sonlu Elemanlar Yöntemi, Ansys, 3D Kafes Sistemleri, Mekanik ve Elastik Gerilme.

Cite

Taskaya, S., (2018). "Investigation of mechanical and elastic stresses in ANSYS program by finite elements method of 3D lattice roof model”, Mugla Journal of Science and Technology, 4(1), 27-36.

\section{Introduction}

A carrier system; screws, bolts or welded ends. Carrier systems; they provide practical solutions to many structural engineering problems such as power transmission towers, bridges and structures. Solutions to statically specific carrier system problems, many of which are found in traditional mechanical books, can be analyzed with the help of node balancing or truncation methods. However, these two methods do not provide information on the placements because the structural elements are assumed to behave rigidly. Furthermore, if the carrier system elements are considered to be rigid bodies, it is impossible to analyze the static problems that are unclear with these methods. The finite element method makes it possible to remove rigid body constraint from the middle and solve these problems [1]. In parallel with the development of the finite element method, end-user package programs are also increasingly used for commercial purposes such as ANSYS and ABAQUS. D. Dubina and R. Zaharia have experimentally and numerically investigated the mechanical behaviors of cold-worked steel bearing systems with semi-rigid interconnected structures [2].

A. Fülöp and M. Ivani have experimentally examined the behavior of an exemplary space frame system consisting of elements with semi-rigid connections under different loads [3]. N. Ali et al. We have developed a genetic algorithm based on the finite element method and have 
reported that the analyzes obtained by optimizing the shape and size of some sample systems of the plane and space carrier are compatible with other existing classical approaches in the literature [4]. C. D. Roover et al. A bridge design made from IPC (inorganic phosphate cement) sandwich panels has been calculated by the analytical and finite element method, thus demonstrating the utility of the finite element method to control the stress distribution in panels and fittings [5]. Dr. Max Mengeringhausen developed space lattice systems and used them in the 1940s. By developing spacecraft systems, Mengeringhausen revealed the best example of clarity, beauty and functionality in the architecture that emerged at the "Bauhaus" school. The first constructions were made in 1942 with the rod knot system developed by Mengeringhausen. Bar node systems have quickly become industrialized systems in large programs [6]. The unit element of the space lattice carrier systems is a quadruple consisting of six rods and four knot points. Such a quadruple can easily be enlarged with three bars, each not in the same plane. Bar combinations are made with patented knot points that provide ease of assembly. The polyhedral structure was a glimpse of the emergence of the Alexander Graham Bell system, which used a three-way version in 1907. The glider was used as a beam system on the wings of the wing aircraft. In the 1940s, Max Mengeringhausen developed this system and began using spacecraft systems in construction [7]. Rottensteiner et al. (2014), the identification of roof planes from the analysis of three-dimensional (3D) point clouds and Digital Surface Models (DSMs) is an active research and application issue [8]. Jochem et al., (2009) developed a model of building volumes in 3D city models that incorporates roof planes in a model-friendly way [9]. Huang et al. (2013), used a generative model based on a primitive library for roofing and reconstruction. There have also been attempts to mix approaches from top to bottom [10]. As suggested by Vitti (2012), areas with uniform gradient (i.e. planar) patches and boundaries (i.e. roof edges and eaves) were detected by using the global variability model, a second-order model suggested by Blake and Zisserman (1987) [11-12]. Ohtake et al., (2004), in the fastening edge on the triangle meshes, realized by analyzing base curves and derivatives [13]. Rottensteiner (2003), applied a region growing model on normal vectors in the production of 3-dimensional building models [14]. Wang et al. (2013) considered the normal vectors as points on unit sphere and then segmented planes and other orderly surfaces for detection [15]. Gür AK. et al. (2017), mechanical stress analyzes were carried out under the loads of 15000 and $10000 \mathrm{~N}$ applied to the 3D truss roof model $\mathrm{F}_{\mathrm{x}}, \mathrm{F}_{\mathrm{y}}, \mathrm{F}_{\mathrm{z}}$ beam axes. By performing elastic-von mises stress analyzes on the $\mathrm{x}, \mathrm{y}, \mathrm{z}$ axes of the model, they investigated the deformation deformations that they showed against the load. As a result of the analyzes, it was observed that the mechanical stresses in the beam axes against the applied load increased [16]. C. D. Roover et al (2002), IPC (inorganic phosphate cement) is designed as a bridge made from sandwich panels were calculated using the analytical and finite element method and under the control of the stress distribution in the panel and connecting elements of finite elements have demonstrated the availability of the method. [17]. Packaged programs developed in accordance with the requirements of the computer technology provide effective use of numerical methods. The finite element method is preferred because of the flexibility it provides in modeling and the ease with which the software implements the method [18]. Moktar Awang steel material occurring in residual voltages to examine the corners joining the different slope shape, headlamps have made experiments with heat input and finite element of these experiments have the analysis program ansys'. Awang studied the influence of process parameters on permanent stresses [19]. N. Ali et al., A genetic algorithm based on the finite element method and that the results obtained by optimizing shape and size on some sample systems of plane and space carrier are in accordance with other existing classical approaches in the literatüre [20].

In this study, after defining the parameters of element type, lattice pipe outer diameter and meat thickness, elasticity and poisson ratio in the lattice model Ansys package program, it is designed as 3 dimension using the finite element method. Mechanical and elastic tensile analyzes were carried out under the loads of 25000 and $20000 \mathrm{kN}$ applied to $\mathrm{F}_{\mathrm{x}}, \mathrm{F}_{\mathrm{y}}, \mathrm{F}_{\mathrm{z}}$ beam axes and $2 \mathrm{MPa}$ pressure to our 3D lattice roof model. Deformation deformations of the model against mechanical stresses in the $\mathrm{x}, \mathrm{y}, \mathrm{z}$ axes and elastic stress stress analyzes were analyzed.

\section{Material and Method 2.1. Ansys Program Modeling of Three Dimensional Roof System}

In this study, the lattice model was designed in the dimensional direction of Fig. 1 in 3D in the Ansys 12.0 package program by the finite element method.

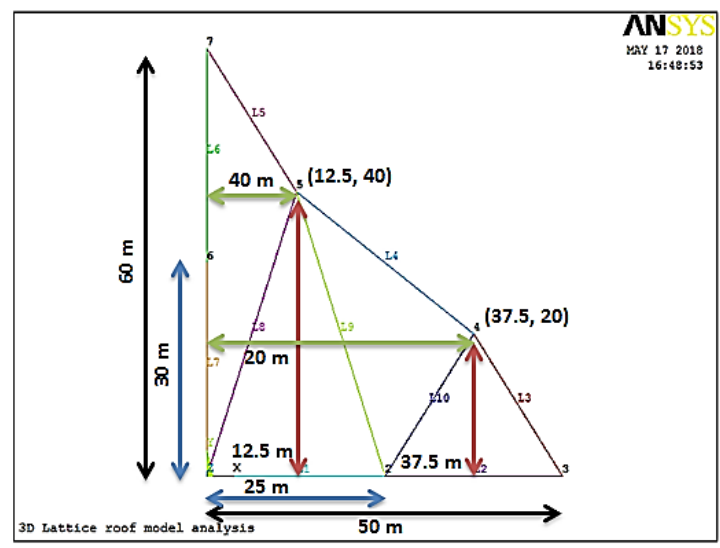

Figure 1. 3D lattice roof modeled wing structure

Diameter and thickness measurements of lattice roof are defined in Ansys software (Fig.2). The material is a standard steel group material and is an isotropic material. System parameters according to the $3 \mathrm{D}$ wireframe model Ansys program is provided in Table 1. 


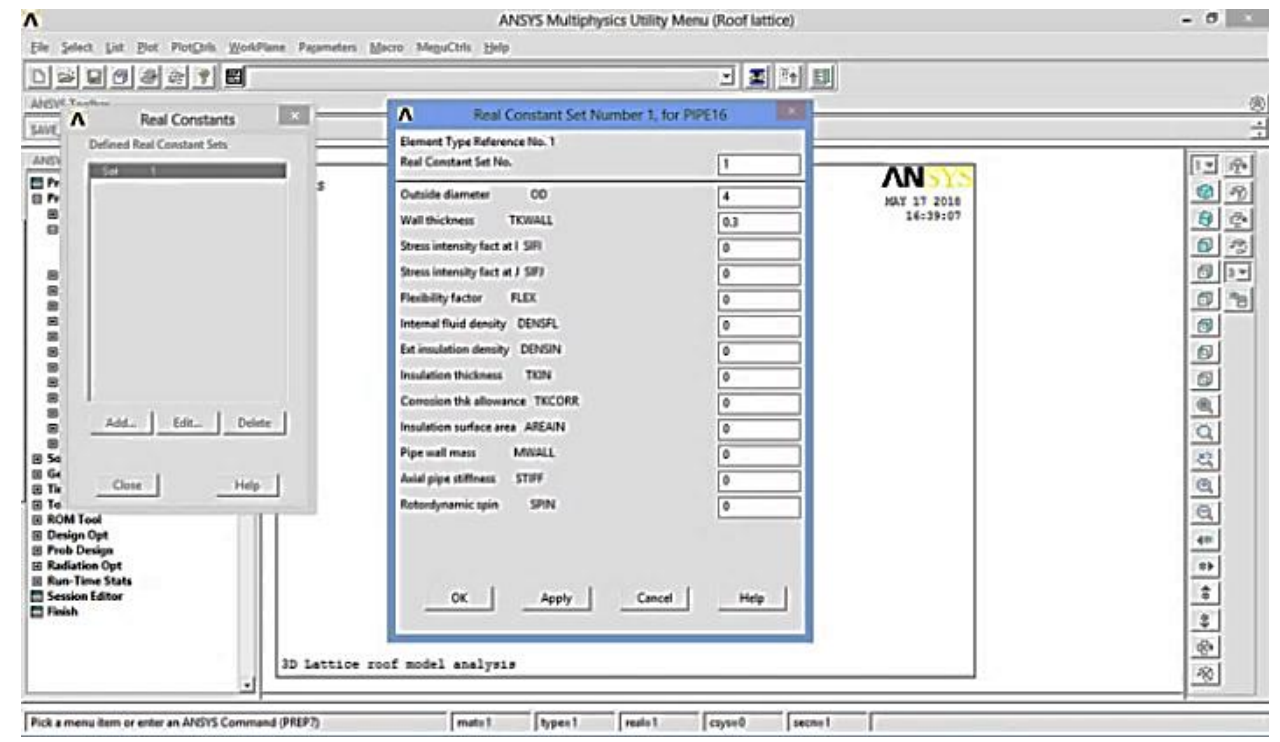

Figure 2. 3D lattice roof modeled diameter and thickness measurements

Table 1. System parameters of 3D grid roof model

\begin{tabular}{ccccccc}
\hline Model Name & $\begin{array}{c}\text { Material } \\
\text { Type }\end{array}$ & $\begin{array}{c}\text { Element } \\
\text { Type }\end{array}$ & $\begin{array}{c}\text { Lattice Pipe Outside } \\
\text { Diameter }(\mathrm{Q})\end{array}$ & $\begin{array}{c}\text { Lattice Pipe Wall } \\
\text { Thickness }(\mathrm{t})\end{array}$ & $\begin{array}{c}\text { Elasticity } \\
\text { Module }\end{array}$ & $\begin{array}{c}\text { Poisson } \\
\text { Ratio }\end{array}$ \\
\hline $\begin{array}{c}\text { 3D lattice } \\
\text { roof }\end{array}$ & İzotropik & $\begin{array}{c}\text { Pipe / elast } \\
\text { straight } 16\end{array}$ & $4 \mathrm{~mm}$ & $0.3 \mathrm{~mm}$ & $210000 \mathrm{kN}$ & 0.3 \\
\hline
\end{tabular}

Ansys 12.0 package program was used to create the model of the 3D roof lattice system. In the model, the coordinates of the nodes of each structure and the nodes forming the elements are introduced to the Ansys 12.0 program with the aid of the prepared data. Our 3D lattice roof model consists of 4 separate cannaments. The keypoint of each blade are given in Table 2. In the Ansys package program, the structural module is selected to perform mechanical analysis as step 1nd. The Ansys program for the steel pipe material lattice structures "pipe / elast straight 16" element type is selected. After introducing the outer diameter of the model and the steel pipe thickness into the system, the elasticity and poisson ratios of the lattice model are entered. The first leaf design of the 3D lattice roof model is created as shown in Fig. 3 by entering the keypoint data in Table 2 into the system. 3D lattice roof wing design model $2 \mathrm{nd}$. left $-\mathrm{x}$ direction entering the system from the data in Table 2 is defined as in Fig. 4 keypoint.

3D lattice roof model is created as shown in Fig. 5 by entering in the system $\mathrm{z}$ direction from the keypoint data in Table 2. As shown in Fig. 5, after the keypoints are installed in the system, the wing pipes are assembled by looking at the model from the right perspective from the system so that there is no confusion in the design to form the wing pipes. At the end, the 3D lattice roof model is viewed from the isometric perspective.

$3 \mathrm{D}$ lattice roof model right rear $4 \mathrm{nd}$. the wing design is created as shown in Fig. 6 by entering the system in the $\mathrm{z}$ direction from the keypoint data in Table 2.
Table 2. 3D lattice model keypoint wing measures

\begin{tabular}{|c|c|c|c|}
\hline $\begin{array}{c}\text { 3D Wing Keypoint Measures of } \\
\text { Lattice Roof Model }\end{array}$ & $\mathbf{x}$ & $\mathbf{y}$ & $\mathbf{z}$ \\
\hline \multirow{7}{*}{1 st Lattice Wing } & 0 & 0 & 0 \\
\hline & 25 & 0 & 0 \\
\hline & 50 & 0 & 0 \\
\hline & 37.5 & 20 & 0 \\
\hline & 12.5 & 40 & 0 \\
\hline & 0 & 30 & 0 \\
\hline & 0 & 60 & 0 \\
\hline \multirow{4}{*}{2 nd Lattice Wing } & -25 & 0 & 0 \\
\hline & -50 & 0 & 0 \\
\hline & -37.5 & 20 & 0 \\
\hline & -12.5 & 40 & 0 \\
\hline \multirow{4}{*}{3 rd Lattice Wing } & 0 & 0 & 25 \\
\hline & 0 & 0 & 50 \\
\hline & 0 & 20 & 37.5 \\
\hline & 0 & 40 & 12.5 \\
\hline \multirow{4}{*}{4 th Lattice Wing } & 0 & 0 & -50 \\
\hline & 0 & 0 & -25 \\
\hline & 0 & 20 & -37.5 \\
\hline & 0 & 40 & -12.5 \\
\hline
\end{tabular}




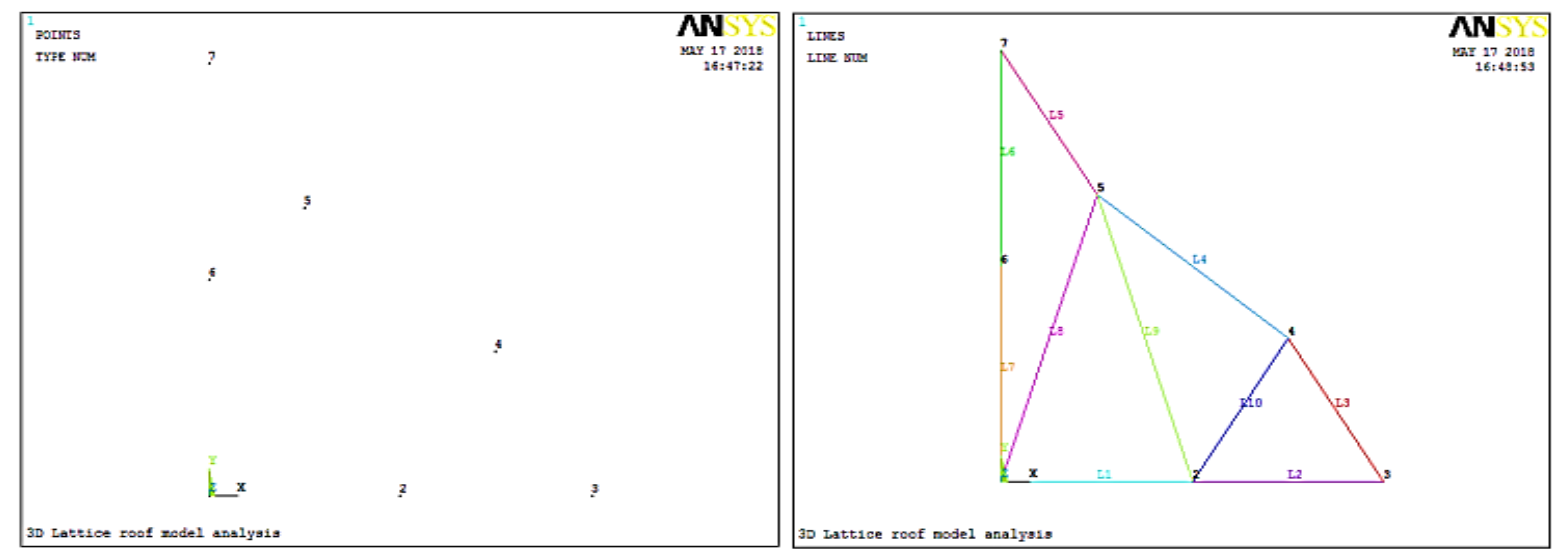

Figure 3. 3D lattice roof model 1nd. right wing design

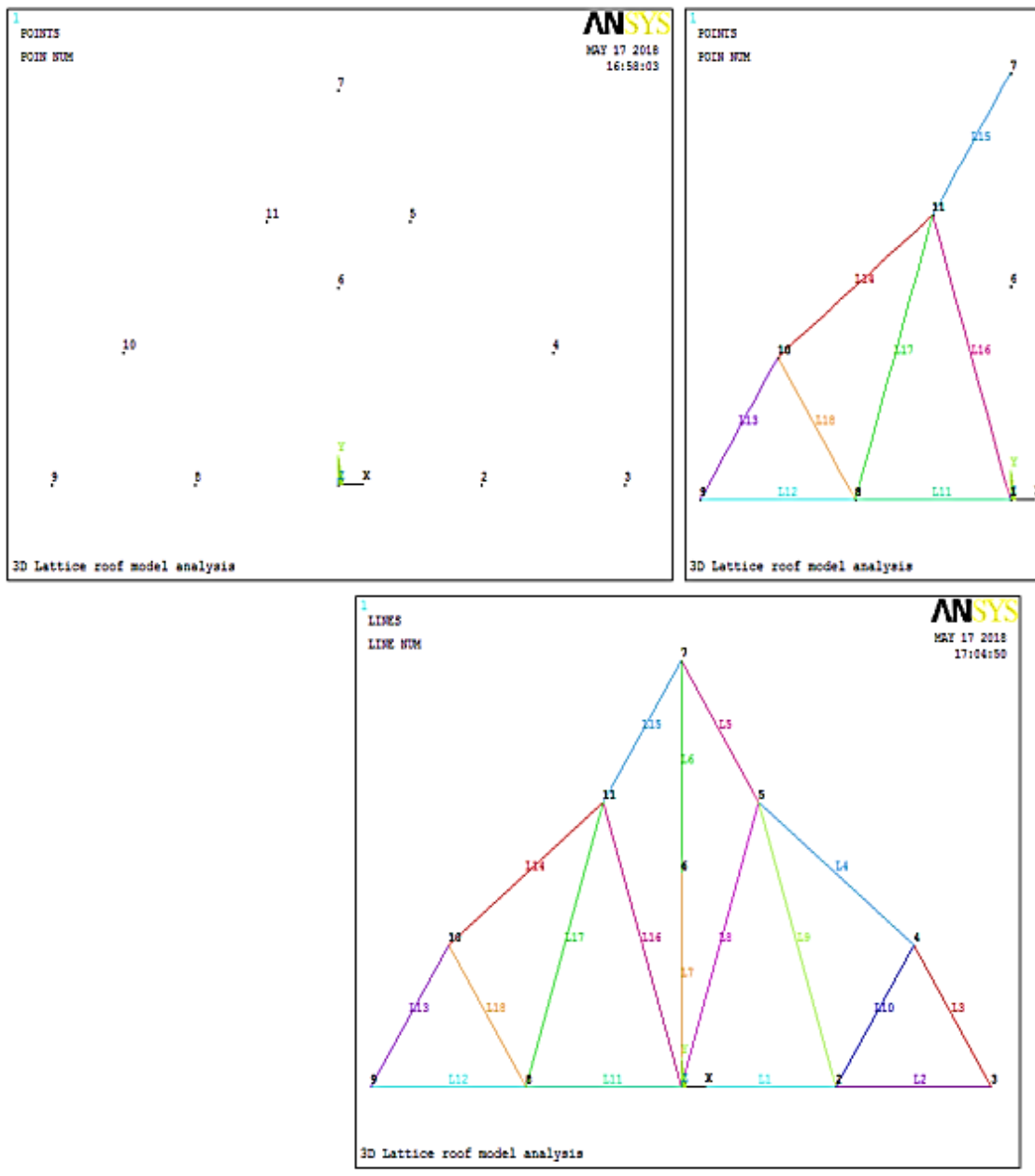

Figure 4. 3D lattice roof model $2 \mathrm{nd}$. left wing design 


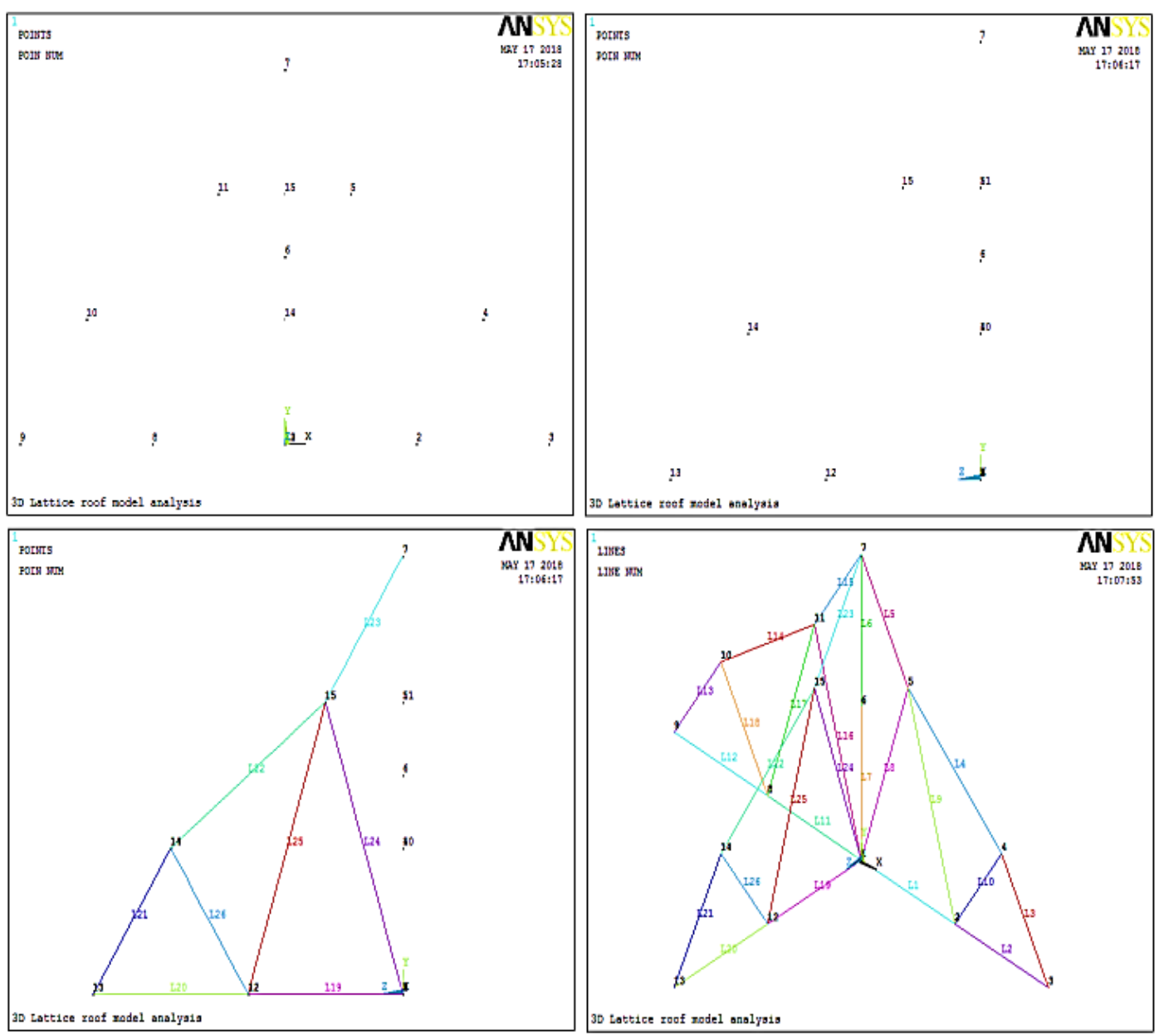

Figure 5. 3D lattice roof model rear left 3nd. wing design (Right and isometric perspective directions)

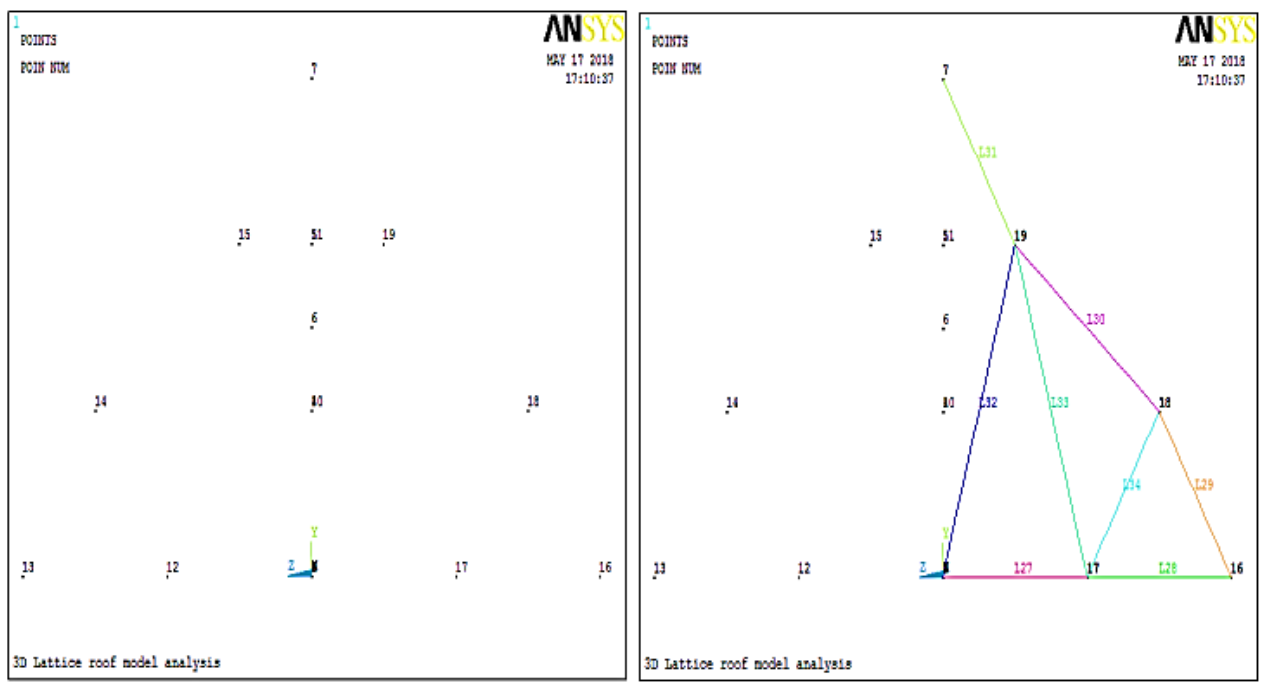

Figure. 6. 3D lattice roof model rear right 4nd. wing design

After the 3D lattice roof model is created, the meshing is performed on the model elements. The second meshing system is selected from structural steel tube and the meshing Fig. 7 in such an ideal model of division we lattice roof. 


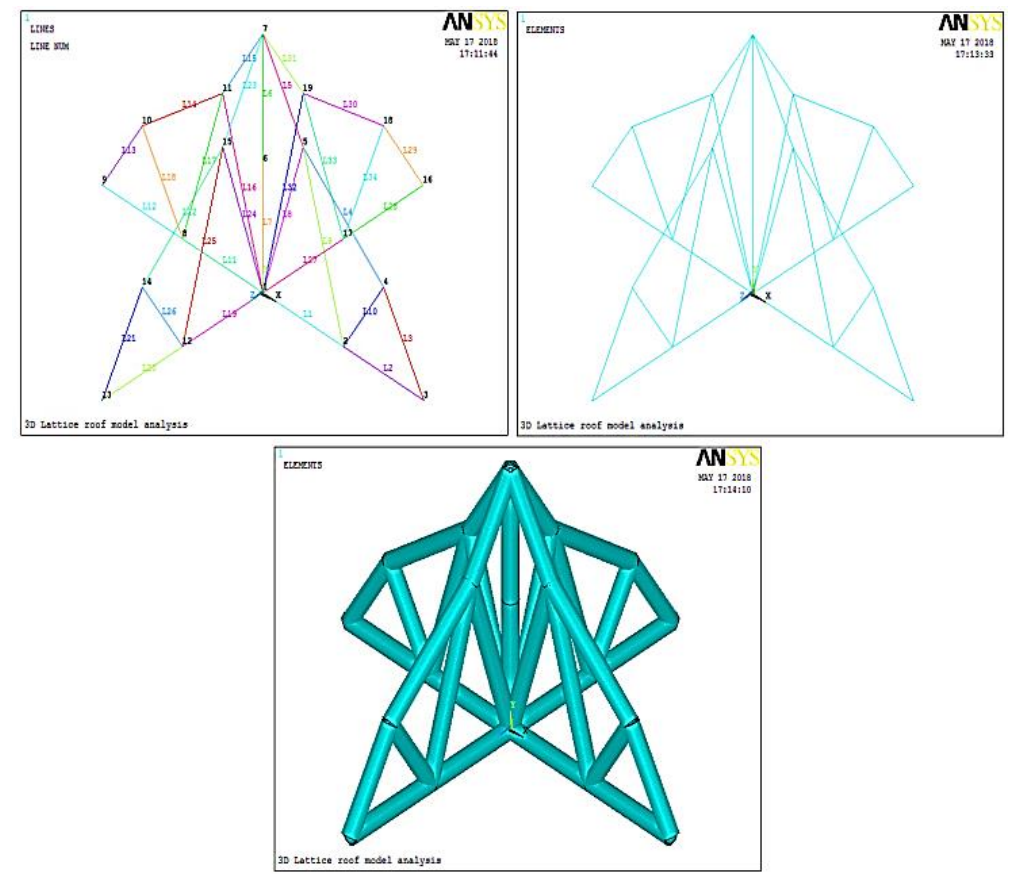

Figure 7. Mesh modeling of 3D lattice roof model (segmentation) operation

3D mesh model from the roof corner nodes fixing process is carried out as in Fig. 8. After fixing, force and pressure are applied to the lattice model in the direction of $F_{x}, F_{y}$, $\mathrm{F}_{\mathrm{z}}$ beam axes from the upper nodal point. In the direction of $F_{y}-25000 \mathrm{kN}$, the force of $20000 \mathrm{kN}$ in $F_{x}$ and $F_{z}$ directions and the pressure of $2 \mathrm{MPa}$ in the steel pipes are analyzed to analyze the results of deformation, mechanical and elastic stresses in the 3D lattice model Ansys package program.
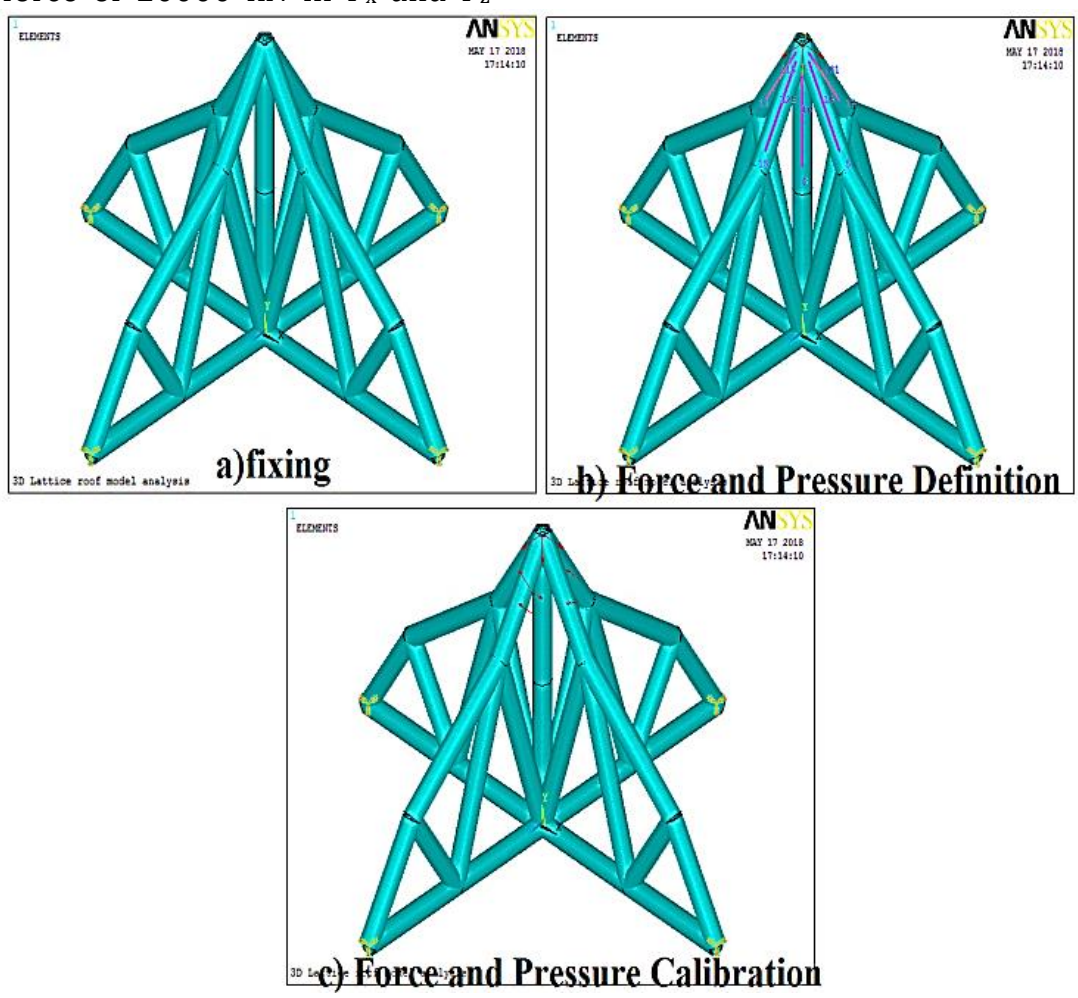

Figure 8. a) Fixing Process, b) Force and pressure application to beam axes c) Force and pressure calibration

\section{Results}

The 3D lattice roof model was analyzed with 68 elements and 53 nodes, and the deformation nodal points in the beam axes of the roof model were analyzed in Fig. 8 by the effect of force and pressure applied from the upper nodal point. 


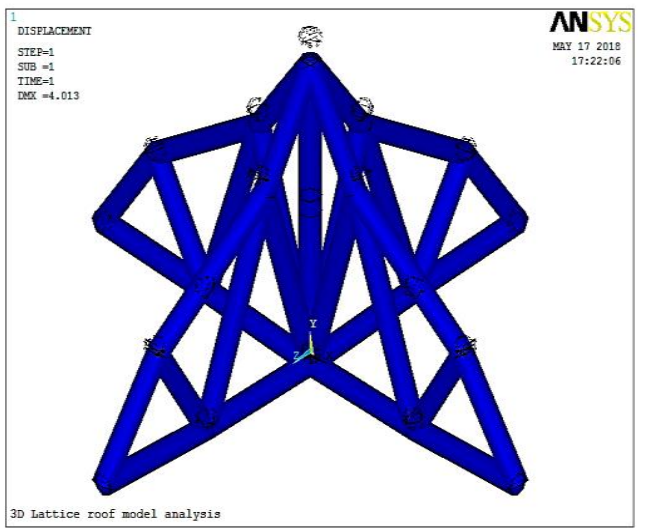

Figure 9. Deformation of the Beam Axes of the 3D Lattice Roof Model Node Points

3D model lattice vector analysis of the roof is indicated in Fig. 10. During the reaction the color distribution shown in the form of lattice pattern across the load and pressure applied to the beam axis and a vector line analyses were obtained with the systematic analysis simulation.

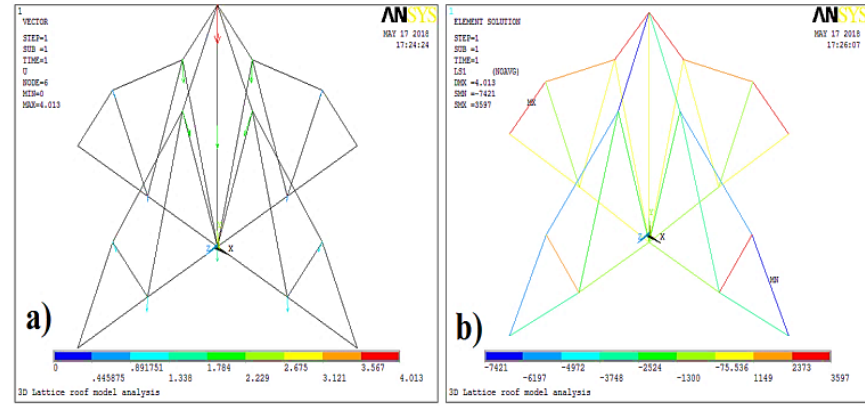

Figure 10. a) Vectoral and b) Line analysis of the beam axes of the 3D lattice roof model

The mechanical and elastic stress tensions of the 3D cage roof model against load and press applied to the beam axes are shown in Fig. 11 and Fig. 12 In the axes 1, 2 and 3 of the $x, y, z$, and $x y$ axes, the total mechanical and elastic stress intensity and von mises stresses (averages of stresses and shear stresses on the elements) were analyzed separately in the Ansys package program.

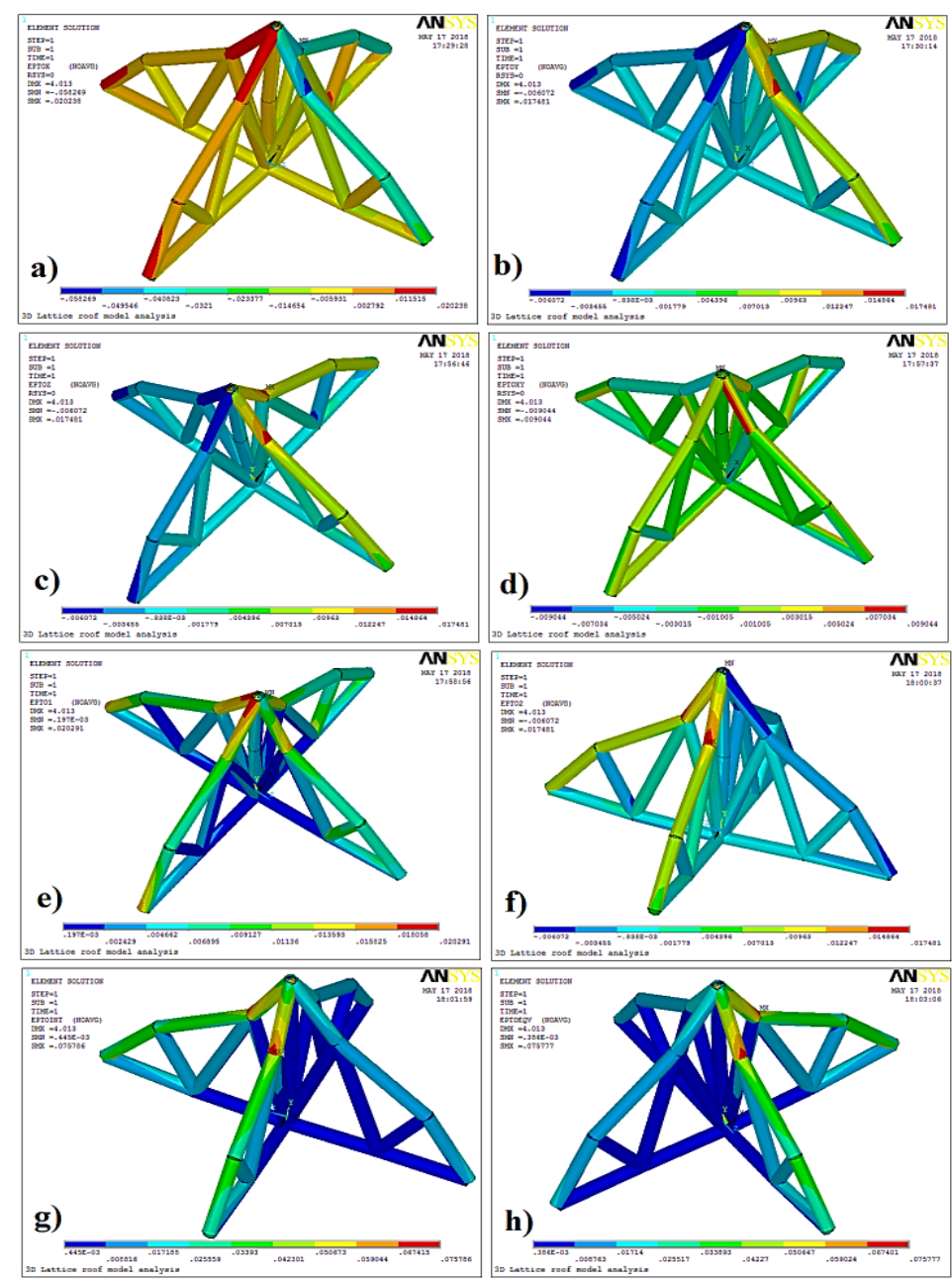

Figure 11. a) Total mechanical stress in the X-axis direction b) Total mechanical stress in the Y-axis direction c) Total mechanical stress in the Z-axis direction d) Total mechanical stress in the XY axis direction e) The total principal mechanical stress on the first main component f) The total secondary mechanical stress on the main composite $2 \mathrm{~g}$ )

Mechanical stress intensity h) Von mises mechanical stress simulation) 
The contour plots of internal forces acting on each member of the roof lattice system under the effect of the applied loads are examined in Fig. 11 and Fig. 12 As analyzed in detail, the effect on the model is max. internal forces, deformations max. and on the beam points.

In the total mechanical stress contour simulations, the mechanical force exerted on the $\mathrm{x}, \mathrm{y}, \mathrm{z}$ axes and the pressure upper and lower beam supporting nodes of the press were observed. It has been investigated that the pressure values are increased more in the upper beam nodes in the xy axis. it was observed that the effect of force and pressure on the principal component axis is widespread in the anterior and posterior wing planes of the 4 lattice structures and that the mechanical effect of the force effect on the front lattice axis on the 2 nd. principal axle is more mechanical in the beam knots. This can be expressed as a change in the outer diameter of the lattice pipe and the thickness of the meat at the axes nodes, depending on the element type of the Ansys packet software. The mechanical stress intensity and the force and pressure at shear stresses occurring between the nodes showed more intensity in the frontal lattice planes.

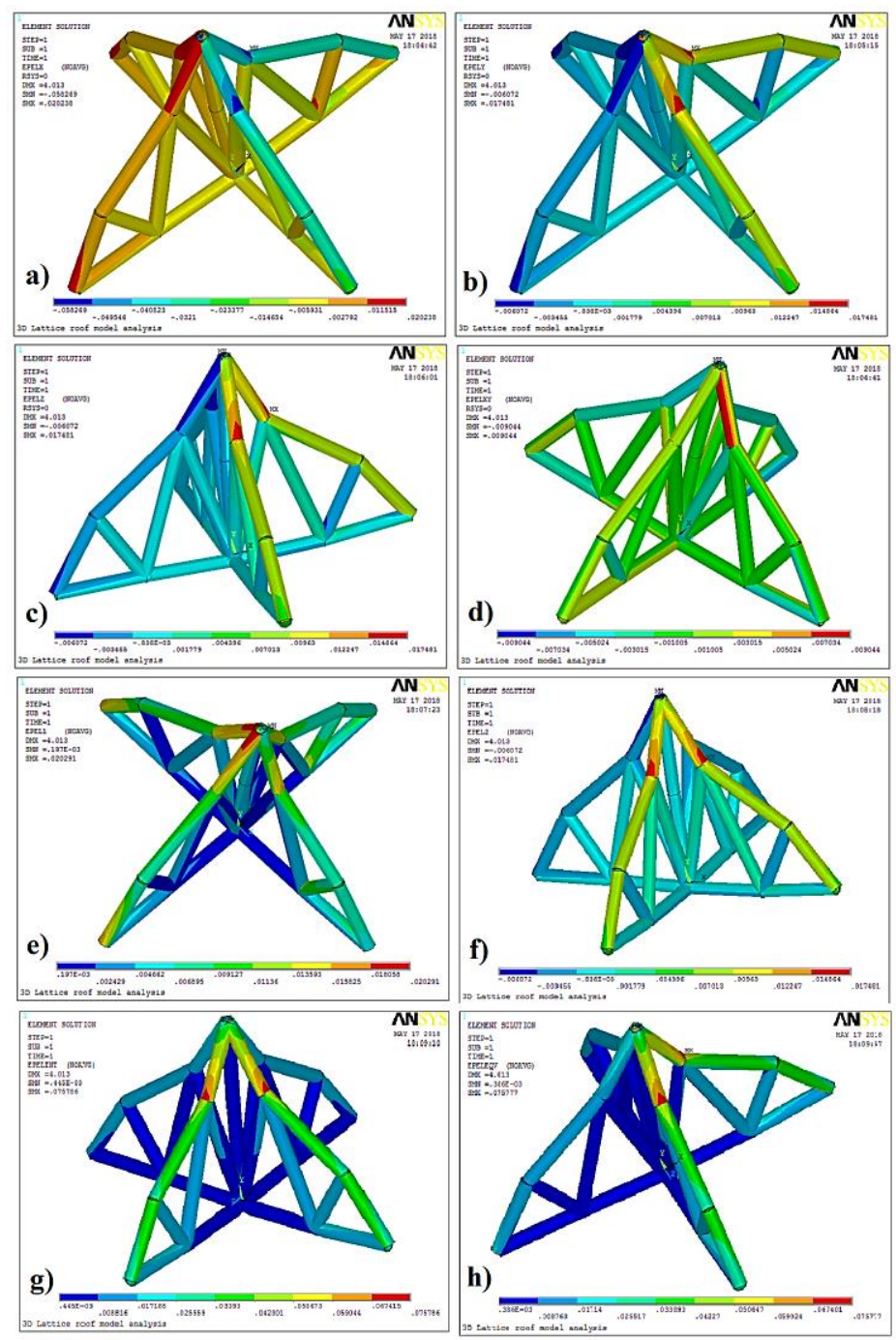

Figure 12. a) Elastic stress in the X-axis direction b) Elastic stress in the Y-axis direction c) Elastic tensile stress in the Zaxis direction d) Elastic stress in $\mathrm{X}, \mathrm{Y}$ axis direction e) Elastic stress at the first main component axis f) Elastic stress on the 2nd main component axis g) Elastic stress intensity h) Von mises elastic stress contour simulation

The contour simulation of elastic stress analysis was determined not cause a different stress effects due to mechanical stresses. In rigidity effect maintenance, it is investigated that force and pressure increase in the upper beam support points between $\mathrm{x}, \mathrm{y}, \mathrm{z}$ axes, and elastic tension density increases in 4 separate lattice fins in the 1 st main composite axes, while the 2 nd. main effect increases in the axial front lattice wing. Elastic stress intensity and von mises shear stresses are more elastic strain in the front lattice fins. Because the supporting node points of the 3D lattice model are expressed in terms of forces and pressures in terms of the front beam node (points) in constructive terms. 


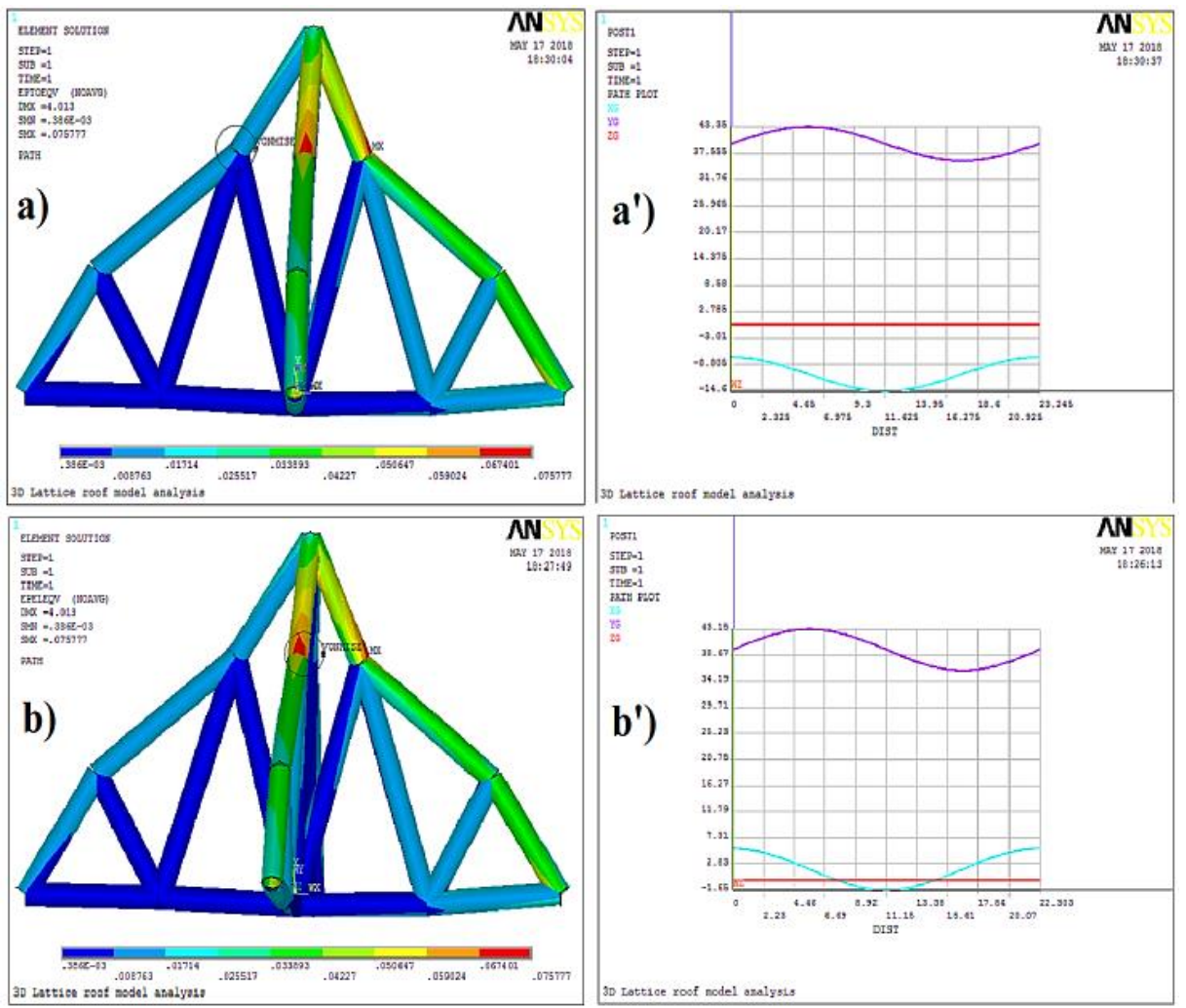

Figure 13. a) -a ') Voltage graphics of the total mechanical stresses on the $x, y, z$ axes in the upper beam node b) -b ') Voltage graphics of the elastic strains on the $\mathrm{x}, \mathrm{y}, \mathrm{z}$ axes in the upper beam node

In the graphical analysis of the mechanical stress contour simulation based on the $\mathrm{x}, \mathrm{y}, \mathrm{z}$ axes taken from the upper beam node, the mechanical force at the $y$ axis and the pressure increase at this node, increase and decrease at the $\mathrm{x}$ axis and leave a constant effect on the $\mathrm{z}$ axis.

In the graphical analysis of the elastic stress contour simulation based on the $\mathrm{x}, \mathrm{y}, \mathrm{z}$ axes taken from the side of the upper beam side, the mechanical force in the $y$ axis as well as the mechanical force and the pressure increase at this node, increase and decrease in the $\mathrm{x}$ axis and leave a constant effect below the $\mathrm{x}$ axis in the $\mathrm{z}$ axis showed no elastic strain.

\section{Conclusions and Suggestions}

In the graphical analysis of the mechanical stress contour simulation based on the $\mathrm{x}, \mathrm{y}, \mathrm{z}$ axes taken from the upper beam node, it is analyzed that the mechanical force on the $y$ axis and the pressure increase in this node, increase and decrease in the $x$ axis and leave a constant effect on the $\mathrm{z}$ axis.

$>$ In the graphical analysis of the elastic stress contour simulation based on the $\mathrm{x}, \mathrm{y}, \mathrm{z}$ axes taken from the upper beam side node, it is also found that the mechanical force in the $y$ axis and the pressure increase at this node, increase and decrease in the $x$ axis and leave a constant effect below the $\mathrm{x}$ axis in the $\mathrm{z}$ axis showed no elastic strain.

$>$ As it has been discussed with analysis 3D model in accordance with the lattice roof, with repeated applications, both economically and in terms of possible to obtain the most reliable construction in terms of structural strength.

$>$ The contour simulation of elastic stress analysis was determined not cause a different stress effects due to mechanical stresses.

$>$ Taking into account the coordinate points between the axes, the mechanical and elastic stresses are increased in the upper beam nodes, and the tensile and compressive effects between the knots are increased in the elastic stresses as well as in the total mechanical effect [16,21]. The residual stresses between the beam nodes also show elastic behavior between the lower knot points as well as in the plate steels [21]. The materials can be compared with each other by changing different modeled geometries, different field measurements, orientation angles, material type, different core layer, element type, mesh type, load amount, Materials with complex geometries in the application area can be prototyped and compared with each other by converting the various finite element simulations programs (such as ABAQUS, Apex, Nastran) to simplest. In this way, many test analyzes (such as structure, thermal, vibration, and mechanical, static, dynamic) can be made from simple geometric models.

\section{References}

[1] Moaveni, S., "Finite element analysis theory and application with Ansys," Prentice Hall, New Jersey, 1999. 
[2] Dubina, R., Zaharia, D. "Cold-formed steel trusses with semi-rigid joints," Thin-Walled Structures, vol. 29, 273-28, 1997.

[3] Fülöp, M., Ivanyi, A. "Experimentally analyzed stability and ductility behaviour of a space-truss roof system," Thin-Walled Structures, Vol. 42, No. 2, pp. 309-320, 2004.

[4] Behdinan, Z., Ali, N. Fawaz, K. "Applicability and viability of a GA based finite element analysis architecture for structural design optimization," Computers and Structures, vol. 81, 2259-2, 2003.

[5] Rover, H., C. Vantomme, D., Wastiels, J., Croes, J., Cuypers, K., Taerwe, H., Blontrock, L. "Modelling of an IPC-concrete modular pedestrian bridge," Computers and Structures, vol. 80, 2133-2, 2002.

[6] Bedford A. and Fowler W. "Statics Engineering Mechanics," Wesley Publishing Company, vol. 624p, 1995.

[7] Makowski, Z.S., "Space Structures of Today and Tomorrow Space Structures (ed. H. Nooshin), Guildford," Elsevier, 1984.

[8] Rottensteiner, F., Sohn, G., Gerke, M., J.D. Wegner, Breitkopf, U., Jung. J. "Results of the ISPRS benchmark on urban object detection and $3 \mathrm{~d}$ building reconstruction", ISPRS J. Photogram. Remote Sens., 93, pp.256-271, 2014.

[9] Jochem, A., Höfle, B., Rutzinger, M., Pfeifer, N. "Automatic roof plane detection and analysis in airborne LiDAR point clouds for solar potential assessment", Sensors, 9, pp. 5241-5262, 10.3390/s90705241, 2009.

[10] Huang, H., Brenner, C., Sester, M. “A generative statistical approach to automatic 3D building roof reconstruction from laser scanning data", ISPRS J. Photogram. Remote Sens., 79, pp. 29-43, 10.1016/j.isprsjprs.2013.02.004, 2013.

[11] Vitti, A." The Mumford-Shah variational model for image segmentation: an overview of the theory, implementation and use", ISPRS J. Photogram. Remote Sens., 69, pp. 50-64, 10.1016/j.isprsjprs.2012.02.005, 2012.

[12] Blake, A., Zisserman, A., Visual Reconstruction. MIT Press. 1987.

[13] Ohtake, Y., Belyaev, A., Seidel, H.P.," Ridge-valley lines on meshes via implicit surface fitting", ACM Trans. Graph., 23, pp. 609-612, 10.1145/1015706.1015768. 2004.

[14] Rottensteiner, F. "Automatic generation of highquality building models from LiDAR data", IEEE Comput. Graphics Appl., 23, pp. 42-50, 10.1109/MCG.2003.1242381, 2003.

[15] Wang, Y., Hao, W., Ning, X. Zhao, M., Zhang, J., Shi, Z., Zhang, X. "Automatic segmentation of urban point clouds based on the gaussian map", Photogram. Rec., 28 , pp. 342-361, 10.1111/phor.12041, 2013.

[16] Gür, A.K., Taşkaya, S., Katı, N., Yıldız, T. "Investigation of mechanical stresses of 3D truss roof model by Ansys method", 2nd International Conference on
Material Science and Technology in Cappadocia (IMSTEC'17), October 11-13, 2017, Nevsehir, Turkey, pp. 11-15.

[17] Rover, C., Vantomme D., Wastiels, J., Croes J., Cuypers, K., Taerwe, H., Blontrock, L., H. "Modelling of an IPC-concrete modular pedestrian bridge", Computers and Structures, 80, 2133-2144, 2002.

[18] Hsu,T., Sinha, D.K. "Computet Aided Design: An Integrated Approach, " West Publishing Company, St Paul, 1992.

[19] Awang, M. "The Effects of Process Parameters on Steel Welding Response in Curved Plates," Collage of Engineering and Mineral Resources at West Virginia University, Master of Science, U. S. A., ,vol. 10-21, 80, 2002.

[20] Jiang, J., Collado, C., Keeley, D., Dodd B., "Room Temperature Formability of Particle- Reinforced Metal Matrix Composites", Forging, Extrusion and Deep Drawing Composites, Volume: 26, Issue:11, Pages:785- 789, 1995.

[21] Taşkaya, S. "Investigation of mechanical stresses dependent on press in St 37 steel Ansys program", The Journal of International Manufacturing And Production Technologies (JIMPOT), 1 (1), pp. 39-46, 2017. 